\title{
Rule poses threat to museum bones
}

\section{Law change will allow Native American tribes to reclaim ancient bones found close to their lands.}

Deep in the bowels of dozens of US museums lie caches of unidentified ancient human bones that hold vital clues to the history of the continent's earliest inhabitants. But many Native Americans believe that the remains should to be returned to them, often for reburial or destruction.

A federal rule unveiled on 15 March could give Native Americans a way to claim these bones - and some researchers fear that this could empty museum collections.

The final rule, due to take effect on 14 May, amends the 1990 Native American Graves Protection and Repatriation Act (NAGPRA), which set out steps to correct a history of insensitive handling of bones and funerary objects. The law was a compromise, balancing native rights and those of all Americans who might benefit from scientific study of the remains.

US institutions were required to complete and publish by 1995 inventories of their Native American remains. If tribes could trace the remains to their ancestors or show some other cultural affiliation, they could claim the material from the inventories. Those specimens determined to be not culturally affiliated remained at institutions.

Following years of pressure from Native American groups, the new rule would give them the right to claim specimens without a cultural link if they had been found close to tribes' historic lands. "This is a major departure, going way beyond the intent of the original law," says John O'Shea, a curator at the University of Michigan Museum of Anthropology in Ann Arbor, which has about 1,400 specimens considered culturally unaffiliated. Overall, there are more than 124,000 culturally unidentified ancient human remains in US institutions; although estimates vary widely, at least $15 \%$ of these could be affected by the new rule.

Dennis O'Rourke, a population geneticist at the University of Utah in Salt Lake City and president of the American Association of Physical Anthropology, argues that the loss to science would be greater than ever before, because new techniques allowing the extraction of DNA from increasingly ancient bones has boosted the scientific value of such specimens (see Nature 464, 472-473; 2010).

But the National NAGPRA office, the division of the US Department of the Interior that administers the law, says that the rule is in

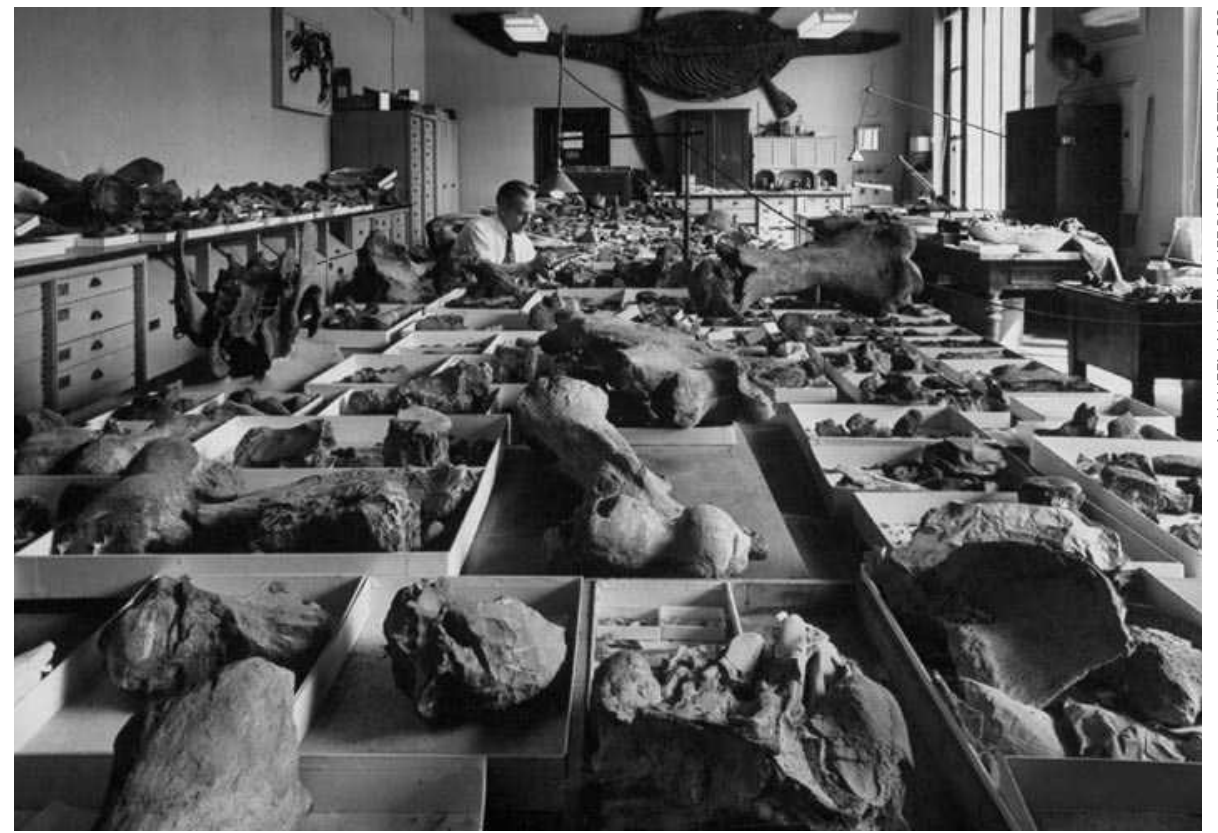

Thousands of ancient human remains held in US museums have not been culturally identified.

keeping with the intent of the 1990 act. Sherry Hutt, programme manager of the NAGPRA office, says that scientists have had sufficient time to study specimens that have been held for decades. "Holding the remains in perpetuity" isn't appropriate, she says.

\section{Local links}

Most scientists say that geographical connections between remains and current tribes may be meaningless, pointing out that the early peoples of the Americas travelled far and wide, as a recent study identifying migration from Siberia to Greenland shows (M. Rasmussen et al. Nature 463, 757-762; 2010). “Geographical proximity is not a great way to define a relationship," says O’Rourke.

The rule, published in the US Federal Register, is open for comment for 60 days - but it will be enacted once that period is over. Ryan Seidemann, a Louisiana state assistant attorney general based in Baton Rouge who is familiar with NAGPRA, called the rule's enactment a form of "guerrilla tactics" that ignores scientists' concerns.

Although Native American tribes are hopeful that the rule will enable them to recover more of their ancestors' bones, they point out that related funerary objects are not covered by it. "As the rule now stands, it won't work," says Mervin Wright Jr, chair of the Pyramid Lake Paiute tribe in Nixon, Nevada. "It is offensive to not include the objects, which for us are a traditional part of the burial." He expects that tribes will lobby to change the rule to address this point.

Some museums - including the American Museum of Natural History in New York, the Field Museum in Chicago, Illinois, and the Peabody Museum of Archaeology and Ethnology at Harvard University in Cambridge, Massachusetts - are discussing whether they will challenge the rule. The issue could have the same import as the long legal fight to study the 9,000-year-old Kennewick man skeleton against Native American wishes (see Nature 436, 10; 2005). In 2004, scientists won that court battle, affirming the principle that bones would be returned only to culturally related tribes.

Anthropologists and archaeologists are also gearing up to debate the rule. Discussions have already been scheduled for the annual meeting of the American Association of Physical Anthropology, which starts on 14 April in Albuquerque, New Mexico, and the Society for American Archaeology meeting, which begins on the same day in St Louis, Missouri.

Rex Dalton 